The European Union and the Modernisation of the People's Liberation Army Navy

The Limits of Europe's Strategic Irrelevance

Mathieu Duchâtel and Alexandre Sheldon-Duplaix

\title{
CpenEdition
}

Journals

Electronic version

URL: http://journals.openedition.org/chinaperspectives/5723

DOI: $10.4000 /$ chinaperspectives.5723

ISSN: 1996-4617

Publisher

Centre d'étude français sur la Chine contemporaine

Printed version

Date of publication: 30 December 2011

Number of pages: $31-41$

ISSN: 2070-3449

Electronic reference

Mathieu Duchâtel and Alexandre Sheldon-Duplaix, « The European Union and the Modernisation of the People's Liberation Army Navy », China Perspectives [Online], 2011/4 | 2011, Online since 30 December 2014, connection on 28 October 2019. URL : http://journals.openedition.org/chinaperspectives/5723 ; DOI : 10.4000/chinaperspectives. 5723 


\title{
The European Union and the
}

\section{Modernisation of the People's}

Liberation Army Navy

\author{
The Limits of Europe's Strategic Irrelevance
}

\section{MATHIEU DUCHÂTEL AND ALEXANDRE SHELDON-DUPLAIX*}

\begin{abstract}
This article argues that the European Union has more interests in the People's Liberation Army Navy (PLAN) modernisation and maritime security issues in East Asia than has traditionally been recognised. The PRC's naval modernisation intersects with the EU's foreign and security policy interests in five main areas: the international Law of the Sea; the risks for Europe of being dragged into an Asian maritime conflict and the safety of European trade with Asian partners; Europe's competitiveness in international markets for naval military systems; the potential for maritime security cooperation against non-traditional threats; and finally, the arms embargo issue and the question of naval technology transfers to China. Through an assessment of the current PLAN modernisation - and Europe's significant contribution to this effort - the article argues that European policy towards China doesn't adequately address these five policy areas.
\end{abstract}

KEYWORDS: People's Liberation Army Navy, European Union, Maritime Security, EU embargo, UNCLOS, anti-piracy, arms sales, naval technologies

S ince 2008, European academics have pointed out a lack of substance in the European Union (EU)-People's Republic of China (PRC) "comprehensive strategic partnership." (1) Chinese Premier Wen Jiabao has proposed his definition of the concept as a "long-term" and "stable" relationship "transcending the differences in ideology and social system" so that it is "not subjected to the impact of individual events that occur from time to time." (2) From an EU perspective, by contrast, a strategic relationship generally entails cooperation beyond purely bilateral issues, to include joint action to maintain international peace, security, and global governance. ${ }^{(3)}$ China's reluctance to develop a security relationship with the EU has led to introspective analyses on Europe's weakness as a security actor, depicting China as not taking the EU as a relevant strategic partner and preferring to put narrow economic and technological objectives at the top of its EU agenda, while Beijing deals with the US more seriously on issues of international security. This view is currently widely shared in European foreign policy circles.

Through an assessment of how the modernisation of the People's Liberation Army Navy (PLAN) impacts Europe's foreign and security policy interests, this article proposes a nuanced perspective of the EU's irrelevance as a security actor in maritime East Asia. Beijing rejects the idea of European involvement in the maritime territorial disputes that undermine regional security, and resists European attempts to include discussions on Asian security matters on the agenda of EU-China meetings. Chinese academics generally consider Europe not to be a legitimate security actor in East Asia. (4)
This article argues that, despite Chinese assertions to the contrary, the PRC's naval modernisation intersects with the EU's foreign and security policy interests in five main areas:

(1) the international Law of the Sea;

(2) the risks for Europe of being dragged into an Asian maritime conflict and the safety of European trade with Asian partners;

(3) Europe's competitiveness on international markets for naval military systems;

\footnotetext{
Mathieu Duchâtel (PhD) is Senior Researcher at the Stockholm International Peace Research Institute, and SIPRI's head China representative. He is also Associate Researcher at Asia Centre, Paris. Alexandre Sheldon-Duplaix is a Researcher and Lecturer at the French Defense Historical Service and Defense College since 1999. He has previously worked as an analyst at the French Ministry of Defense. This paper draws on an Asia Centre (www.centreasia.eu) research project conducted by the two authors on the strategic implications for Europe of China's naval modernisation.

1. The notion of a "comprehensive strategic partnership" was first mentioned by Chinese Premier Wen Jiabao in May 2004. It was then included in the final joint communiqué of the 7th EU-China summit, held in The Hague on 8 December 2004. For examples of articles pointing out the lack of a strategic dimension in the EU-China strategic partnership, see: Charles Grant, Katinka Barysh, Can Europe and China Shape a New World Order?, Center for European Reform, May 2008; François Godement and John Fox, A Power Audit of EU-China Relations, European Council of Foreign Relations, April 2009; Jonathan Holslag, "The Elusive Axis, Assessing the EU-China Strategic Partnership," Journal of Common Market Studies, vol. 49, no. 2, 2011, pp. 293-313.

2. Quoted in Ye Jiang, "Challenges and Opportunities of EU-China Comprehensive Strategic Partnership," Track II Dialogue on EU-Taiwan Relations and the Taiwan Issue, SIIS, Shanghai, 5-6 June 2010, www.swp-berlin.org (consulted on 13 December 2011).

3. Thomas Renard, "The Treacheries of Strategy, a Call for True EU Strategic Partnerships," Egmont Paper no. 45, April 2011.

4. Feng Zhongping, "Promoting Deeper Development of EU-China Relations," in David Kerr and Zhou Fei (eds.), The International Politics of EU-China Relations, Oxford, Oxford University Press, 2007, pp. 267-280.
} 
(4) the potential for maritime security cooperation against non-traditional threats;

(5) the arms embargo issue and the question of naval technology transfers to China.

So far Europe has only addressed two of these issues: the arms embargo and the prospects for maritime security cooperation with the PLAN. The three other issues have been ignored, probably because the EU's foreign policy systematically focuses on cooperation, engagement, and trade, and downplays security and military issues and the long-term evolution of the global balance of power, which is typically seen as being the preserve of the North Atlantic Treaty Organization despite French attempts to define a European Security Policy. As a result, none of the main pillars of the EU's policy towards China addresses the impact of China's military modernisation on Asian regional security, the international order, and European security interests.

For purposes of background, the first section of this article describes the current EU approach towards China's military modernisation. The second section, through an analysis based on equipment and technology production and acquisition, argues that the modernisation of the PLAN is underpinned by the pursuit of a bastion strategy and discusses the implications for Europe of security turbulence in China's maritime periphery. The third section turns to the major contribution of European firms to the modernisation of the PLAN through naval technology transfers. The article then addresses the prospects for maritime security cooperation between Europe and China through the case study of the anti-piracy operation in the Gulf of Aden, and the upcoming Europe/China competition on export markets for naval technologies. In the fifth section, the article argues that the EU embargo on arms sales to China is unlikely to be lifted, primarily as a result of the transatlantic partnership. Finally, the last section explores the consequences for Europe of China's interpretation of the Law of the Sea, and argues that Europe has a strong interest to bring China to full compliance with the UNCLOS.

\section{The paradigm of the EU's strategic irrelevance}

The EU's foreign policy is conceived in normative terms. ${ }^{(5)}$ As far as China is concerned, the main goal of EU foreign policy is to socialise China towards an acceptance of European political norms of liberal democracy through engagement. This policy consists of four main pillars defined the following way on the official webpage of the European External Action Service: "Engage China further, bilaterally and on the world stage, through an upgraded political dialogue; support China's transition to an open society based upon the rule of law and respect for human rights; encourage the integration of China in the world economy through bringing it fully into the world trading system, and supporting the process of economic and social reform; raise the EU's profile in China." (6) In addition, the EU recognises that China's rise as a major power has made it a key partner to address problems of international security and global governance, with the ultimate goal being a "situation where China and the EU can bring their respective strengths to bear to offer joint solutions to global problems." (7)

In this line of thought, stronger Chinese naval forces would enable Beijing to increase its contribution to the international community inasmuch as the PLAN would be better able to participate in the struggle against such non-traditional threats as piracy, terrorism, smuggling, and natural disas- ters. This vision of the future defines the EU's external security agenda of "effective multilateralism." (8)

But China also has unresolved maritime sovereignty disputes with eight countries in Northeast Asia and Southeast Asia that could spiral into armed conflict, and subsequently put European trade interests under threat. Beijing's commitment to a peaceful resolution through dialogue is constantly restated, but China's naval modernisation has already provoked a shift in the national defence policies of its maritime neighbours. Japan and Vietnam are implementing naval modernisation programs aimed at balancing the rise of China's naval power. (9) Besides actively developing counter-anti-access defence technologies, the United States in late 2009 began implementing a new operational "AirSea Battle concept" that directly targets the PLAN. ${ }^{(10)}$ In East Asia, the maritime sphere increasingly is becoming an area of strategic rivalry.

Unfortunately, despite the manifest importance of grasping the implications for Europe of these developments, the EU by and large lacks the capacity to independently assess China's growing maritime power. European policymakers tend to free ride on US expertise, and few European academics engage in PLA studies. ${ }^{(11)}$ Among EU member states, the strategic assessment departments in the Ministries of Defence put limited resources into the study of the modernisation of the PLA, and rarely exchange information with each other. ${ }^{(12)}$

There are indications, however, that Brussels is now willing to integrate Asian military issues into the EU's foreign and security policy towards China. Three elements point in this direction, including:

- the deterioration of maritime security in East Asia since 2008, with incidents in which China has confronted Japan, Vietnam, the Philippines, and the US, all of which have collectively raised concerns that a crisis could erupt that jeopardises European trade and economic interests in East Asia; - repeated requests by China's neighbours asking the EU to issue a statement calling for restraint and point out the lack of transparency of China's military modernisation; and

- the implementation of the Lisbon Treaty, which further federalises European foreign policy with the creation of the European External Action Service (EEAS) and a high representative for Foreign and Security Policy of the EU who also serves as the vice-president of the EU Commission. The EEAS will be equipped with more efficient tools to monitor strategic developments in East Asia.

Furthermore, two member states have gone further in addressing potential risks related to China's military modernisation. France's 2008 White paper on defence identifies the proliferation of ballistic and cruise missiles

5. Zaki Laïdi, EU Foreign Policy in a Globalized World, Normative Power and Social Preferences, Abingdon-New York, Routledge, 2008.

6. www.eeas.europa.eu/delegations/china/eu_china/political_relations/index_en.htm (consulted on 13 December 2011).

7. Communication from the Commission to the Council and the EU Parliament, "EU-China, closer partners, growing responsibilities," 24 October 2006.

8. A Secure Europe in a Better World, European Security Strategy, approved by the European Council held in Brussels on 12 December 2003.

9. Acquisition by Vietnam of Kilo-class attack submarines and development by Japan of a XASM-3 supersonic anti-ship missile appear to be targeting China's aircraft-carrier ambitions (sources: Jane's AirLaunched Weapons, 6 December, 2010; Jane's Underwater Warfare Systems, 12 November 2010).

10. Eric Sayers, Senior Colonel Fan Gaoyue, "Air-Sea Battle: an Exchange," PacNet Newsletter, 17 March 2011.

11. Recently published European work on China's Military includes Jonathan Holslag, Trapped Giant, China's Military Rise, IISS Adelphi Series, no. 416, 2010.

12. Interviews with various officials from European ministries of defence and foreign affairs, Paris, Brussels, 2010 and 2011. 
Table 1 - China's comprehensive approach to maritime security:

security sectors seen by Chinese naval experts

\begin{tabular}{|c|c|c|c|}
\hline Security sector & Interests and stakes & Current threat assessment & Tasks and missions \\
\hline Political security & $\begin{array}{l}\text { Sovereignty, territorial } \\
\text { integrity and protection } \\
\text { of China's rights on sea }\end{array}$ & $\begin{array}{l}\text { Foreign occupation } \\
\text { of Chinese territory }\end{array}$ & $\begin{array}{l}\text { Crisis management, back a } \\
\text { political solution, recover } \\
\text { by force }\end{array}$ \\
\hline Political-military security & National unification & $\begin{array}{c}\text { Taiwan Independence } \\
\text { Movement }\end{array}$ & Contain and divide \\
\hline Political-territorial security & Counter-interference & $\begin{array}{l}\text { US maritime surveillance, } \\
\text { Japanese MSDF* expansion }\end{array}$ & Getting prepared \\
\hline Economic security & $\begin{array}{l}\text { Economic interests resource } \\
\text { exploitation }\end{array}$ & $\begin{array}{l}\text { Resources plundered, } \\
\text { vulnerability of SLOC**, } \\
\text { smuggling }\end{array}$ & Enhance the struggle \\
\hline Societal security & Public security at sea & $\begin{array}{c}\text { Piracy, smuggling, crime, } \\
\text { terrorism }\end{array}$ & Hit and prevent \\
\hline Environmental security & $\begin{array}{l}\text { Maritime ecology } \\
\text { protection }\end{array}$ & Pollution, disasters & Control and prevention \\
\hline
\end{tabular}

* Maritime Self-Defence Forces ** Sea lines of communication

Source: Feng Liang (ed), Zhongguo de heping fazhan yu haishang anquan huanjing, (China's Peaceful Development and Maritime Security Environment), Shijie Zhishi Chubanshe, 2010, p. 293. Author's translation.

as a new vulnerability for Europe, implicitly giving a justification for France's longer-range submarine launched M51 missiles (11,000 km) capable of reaching East Asia and operational since 2010. It addresses Asian and Chinese issues, expressing concern for the EU's 75 percent dependence on oil while China and India's demand is rising, citing the possibility of "competition and possibly even conflict" over energy resources. ${ }^{(13)}$ Stating that Britain currently faces "no major state military threat," London's National Security Strategy issued in October 2010 describes - without referring to China - how some states use cyberspace for espionage "from a safe distance." (14)

\section{The regional priorities of the PLAN's modernisation: Implications for Europe of China's bastion strategy}

The Chinese navy's current objective is to replace its obsolete vessels and extend its radius of operations beyond the first island chain. By 2025, the PLAN will have built a force structure similar to that of the French Navy during the Cold War. It will have expanded the area covered by its air arm, commissioned two aircraft carriers, commissioned six to eight new nuclear attack submarines (Shang-class follow on) for blockade operations beyond the island chains against the adversary's sea lanes of communications, ${ }^{(15)}$ and probably three more Jin-class follow-on ballistic missile submarines to perform counter-attack, deterrence, and anti-access operations. Power projection in Europe's traditional spheres of influence - Africa and the Middle East - is currently not a priority of China's maritime modernisation.
Several Chinese experts defend the need to develop a "Mahanian" navy to protect the expansion of Chinese economic interests. (16) But an analysis focused on equipment procurement suggests the regional priorities that underpin China's naval modernisation.

Chinese strategists tend to display a comprehensive sense of China's maritime vulnerability, including traditional and non-traditional threats (see Table 1). So far, China has not yet elaborated a comprehensive maritime strategy to tackle this wide range of perceived threats in an integrated way, although military and civilian experts have been commissioned to propose ideas and recommendations to integrate threat perceptions and operational doctrine into a single strategy paper. ${ }^{(17)}$ Still, China does have a fairly clear hierarchy of goals. Gaining effective control over its claimed Exclusive Economic Zone (EEZ) in the East and South China Seas stands out as a priority and serves as a guiding principle, albeit a very loose one, for China's maritime policies. This regional priority is driven by sovereignty and economic considerations, but its military rationale is also very

13. The French White Paper on Defense and National Security, 2008, in Documentation Française, Paris, p. 21, p. 86.

14. "A Strong Britain in an Age of Uncertainty: The National Security Strategy" London, The Stationery Office, October 2010.

15. Quoted by Lyle J. Coldstein, Andrew S. Erickson, "China's Future Nuclear Submarine Force, Insights from Chinese Writings," Naval War College Review, Winter 2007, pp. 55-79.

16. Zhang Wenmu, Lun Zhongguo haiquan (About Chinese naval power), Haiyang chubanshe (Ocean Press), 2010; Ni Lexiong, "Zhongguo haiquan zhanlue xuanze de kunjing," Tongzhou gongjin, November 2009; Christopher Hughes, "Reclassifying China's Nationalism, the Geopolitik Turn," The Journal of Contemporary China, vol. 20, no. 71, pp. 601-620.

17. Interview with a Chinese maritime security expert, Beijing, June 2010. 
Table 2 - Current Estimates of Chinese Paramilitary Formations Engaged in Maritime Surveillance

\begin{tabular}{|c|c|c|c|c|c|}
\hline & $\begin{array}{l}\text { Maritime Safety } \\
\text { Administration } \\
\text { of the PRC (MSA) }\end{array}$ & $\begin{array}{l}\text { Fishery Law } \\
\text { Enforcement } \\
\text { Command }\end{array}$ & $\begin{array}{l}\text { China Maritime } \\
\text { Surveillance } \\
\text { Administration } \\
\text { (CMS) }\end{array}$ & $\begin{array}{l}\text { Coast } \\
\text { Guards }\end{array}$ & $\begin{array}{l}\text { Customs, } \\
\text { maritime arm }\end{array}$ \\
\hline $\begin{array}{l}\text { Overseeing } \\
\text { authority }\end{array}$ & $\begin{array}{l}\text { Ministry of } \\
\text { Transportation, } \\
\text { State Council }\end{array}$ & $\begin{array}{l}\text { Ministry of } \\
\text { Agriculture, } \\
\text { State Council }\end{array}$ & $\begin{array}{l}\text { State Oceanic } \\
\text { Administration }\end{array}$ & $\begin{array}{l}\text { Ministry of Public } \\
\text { Security }\end{array}$ & $\begin{array}{c}\text { General } \\
\text { Administration of } \\
\text { Customs of the PRC }\end{array}$ \\
\hline Name in Chinese & $\begin{array}{c}\text { Zhongguo jiaotongbu } \\
\text { haishiju haixun } \\
\text { 中国交通部 } \\
\text { 海事局海巡 }\end{array}$ & $\begin{array}{l}\text { Zhongguo nongyebu } \\
\text { Zhongguo yuzheng } \\
\text { 中国农业部 } \\
\text { 中国渔政 }\end{array}$ & $\begin{array}{l}\text { Guojia haiyangju } \\
\text { zhongguo haijian } \\
\text { 国家海洋局 } \\
\text { 中国海监 }\end{array}$ & $\begin{array}{c}\text { Gongan bianfang } \\
\text { haijing } \\
\text { 公安边防海警 }\end{array}$ & $\begin{array}{c}\text { Zhongguo haiguan } \\
\text { 中国海关 }\end{array}$ \\
\hline Missions & $\begin{array}{l}\text { Ensuring the } \\
\text { safety of traffic }\end{array}$ & $\begin{array}{l}\text { Prevent illegal } \\
\text { fishing, enforce } \\
\text { fisheries claims }\end{array}$ & $\begin{array}{l}\text { Environmental } \\
\text { protection }\end{array}$ & $\begin{array}{c}\text { Public security, } \\
\text { national law offences }\end{array}$ & $\begin{array}{l}\text { Anti-smuggling } \\
\text { in ports }\end{array}$ \\
\hline Type of ships & UNARMED & ARMED & $\begin{array}{c}\text { ARMED } \\
\text { (light guns, } \\
\text { machine guns) }\end{array}$ & $\begin{array}{c}\text { ARMED } \\
\text { (37mm guns), some } \\
\text { anti-aircraft } \\
\text { machine guns }\end{array}$ & ARMED \\
\hline $\begin{array}{l}\text { Estimation of the } \\
\text { number of ships }\end{array}$ & $\begin{array}{l}200+\text { patrol boats } \\
\text { Only two over } \\
1000 \text { tonnes }\end{array}$ & $\begin{array}{l}\text { 100+ patrol boats } \\
\text { 10- decommissioned } \\
\text { PLAN ships }\end{array}$ & $70+$ patrol boats & $\begin{array}{c}\text { 100+ Type- } \\
218 \text { patrol boats. } \\
\text { Two former Jianghu- } \\
1 \text { frigate }\end{array}$ & $150+$ patrol vessels \\
\hline Comments & $\begin{array}{l}\text { Will receive a } \\
5400 \text { tonne cutter } \\
\text { in } 2012\end{array}$ & $\begin{array}{l}\text { - The Yuzheng- } 310 \text { is } \\
\text { currently its only heli- } \\
\text { copter-carrying ship } \\
\text { - The Yuzheng- } 311 \text { is a } \\
\text { former PLAN subma- } \\
\text { rine-salvage vessel } \\
\text { - Sent to the } \\
\text { Diaoyu/Senkaku in } \\
\text { November } 2010 \text { at the } \\
\text { height of the dispute } \\
\text { with Japan. }\end{array}$ & & & \\
\hline
\end{tabular}

Source: Feng Liang (ed), Zhongguo de heping fazhan yu haishang anquan huanjing, (China's Peaceful Development and Maritime Security Environment), Shijie Zhishi Chubanshe, 2010, p. 293. Author's translation.

strong. Establishing sea and air superiority over the area claimed as Chinese maritime territory would enable China to enforce a naval bastion strategy ( haijun lengbao zhanlue 海军棱堡战略). Accordingly, in establishing control over the deep waters in the East and South China Seas, China would secure space for its strategic submarines to operate safely from air threats and perform nuclear deterrence missions.

There seems to be no intention in China to build a carrier-centred navy focused on power projection, despite some analyses suggesting the contrary. ${ }^{(18)}$ Although no tactical guideline has ever been published on the use of aircraft carriers, there are reasons to think that they are most likely going to be used to help protect China's strategic submarine fleet's area of operations; extend the fleet's radius of operations out across the first island chain; enforce China's sovereignty claims in the South China Sea; and perform high-profile humanitarian operations to increase China's military diplomatic influence and soft power. This can be traced back to the history of China's aircraft carriers ambitions.

The current interest in aircraft carriers seems to have originated with Liu Huaqing's visit onboard the USS Kitty Hawk in May 1980. Liu "immedi- ately advocated the development of aircraft carriers to the PLA General Staff and created a course for future carrier's captains." According to Liu, justification for aircraft carriers found a rationale in the Taiwanese puzzle:

When we were focusing on the Taiwan Strait issue [1994] we realised that using land based aviation was a waste because we would increasingly need more planes and more air bases. And if we developed an aircraft carrier, we would not need to increase the total number of planes. We would just need to modify them... The aircraft carrier would become a force multiplier, augmenting the fire power of the whole force. ${ }^{(19)}$

By 2015 , China should be able to produce about $15-20$ carrier-capable aircraft and train enough pilots to give its carrier a basic capability as an air defence platform, similar to those of the Russian Kuznetsov, with about

\footnotetext{
18. For example, Fumio Ota, "The Carrier of Asia-Pacific Trouble," Wall Street Journal, 11 August 2011.
}

19. Liu Huaqing, "Liu Huaqing huiyilu" (Memoirs of Liu Huaquing), Beijing, 2004 
20 fighters, 15 helicopters, and four training aircraft. (20) China has built copies of the Russian fighter-bomber Su-33 (J-15) and is producing its own carrier-flight trainer, the J-9. (21) Having acquired the Ka-31 early warning helicopter from Russia, China is also developing a small carrier-borne early warning plane. (22) The ex-Varyag's military potential should be considered as representing one eighth that of an American aircraft carrier and one fourth that of the current French carrier with limited strike outside of YJ83K missiles. ${ }^{(23)}$

The ex-Varyag should be used in China's maritime periphery, first for training in the Yellow Sea in the immediate period after it completes its sea trials, later in the South China Sea, where it can be used to counter the territorial claims of China's small neighbours to features of the Spratly islands. The construction of a new submarine base at Sanya on Hainan Island suggests that the new strategic submarines will also be based in the South China Sea. Safeguarding the patrol areas of the SSBNs (24) would conform to a historically Soviet-inspired "bastion" concept of carrier employment. Such an approach would assign a defensive mission for the carrier, using it to protect the PLAN's SSBNs so as to create the conditions for a credible second strike capability by keeping US submarines, ships, and aircraft away from China's maritime periphery. The Taiwan contingency also remains a potential arena in which the carrier may be employed. From a military perspective, the characteristics of the ex-Varyag would enable her to attack Taiwan's east coast from Hainan using her fighter wing to protect its submarine patrol areas from Japanese and US patrol maritime aircrafts during a Taiwan confrontation. A Chinese carrier could also participate in humanitarian relief operations, and provide strategic support for repatriation operations such as those associated with the evacuation of PRC nationals from Libya in early 2011. Outside of these roles, it seems unlikely that China would employ for offensive operations an asset designed for securing China's peripheral areas.

Underwater weapons represent a powerful dimension of China's area denial architecture. China sees the submarines as an asymmetric answer to delay the progression of US naval forces while the PLA would try to secure victory in Taiwan. To perform this area denial strategy, it is likely that China will field up to 20 air independent propulsion submarines and 30 conventional submarines within the next ten years to extend "the reach of naval defence" across the first island chain (i.e., out to 500-1000 nautical miles). Chinese authors appear to believe that anti-submarine missions should be left to the conventional submarine fleet and to the use of minefields.

All new Chinese conventional submarines are armed with anti-ship cruise missiles and some with land-attack cruise missiles. The modern and conventional submarines (i.e., the Kilo, Song, and Yuan-class boats) would stand a good chance of remaining undetected while attempting to ambush US task forces. In addition, China may use Russian super-cavitating, high-speed underwater rockets (Skvall) and already fields Russian wakehoming (53-65) and anti-submarine (Test-71) torpedoes that are difficult to evade. Defensive minefields laid in advance could be activated or deactivated when required.

A Chinese naval force of about ten ships reached the Pacific at the beginning of 2010 by following the shores of Okinawa and Miyako, causing consternation in Japan and demonstrating the PLAN's ability to break out of the inner island chain. Within ten years China should have about 20-22 air defence and cruise missile destroyers, 25 air defence frigates and 30 patrol corvettes. Destroyers will be essential in protecting China's future aircraft carrier(s). The PLAN's best destroyers (052B/C) and frigates (054A) are already attached to the Southern fleet where the future carrier will most likely be based. (25) The 052C (Luyang II) destroyer has been chosen as the preferred class with the third and fourth launched in 2010-2011 at the new Jiangnan shipyard. By 2020, China will have about 20-22 air defence and cruise missiles destroyers, compared with only 13 at present. Some of the new ships will have better anti-submarine capabilities than China's current fleet. They will replace the remaining nine Luda (051) vessels.

China does not have enough destroyers to meet its needs, so it must continue producing frigates. A further 15 frigates of 054A Jiangkai II-class, or modified versions of this type, will probably be built by 2020 for a total of at least 25. A smaller corvette (056), less sophisticated and less costly than the Jiangkai II, should replace the obsolete Jianghus. (26)

In a specialised journal published by the China Shipbuilding Industry Corporation, Jiang Yu (a pen name) estimates that by 2020 the naval air arm will have 200 long-range attack aircrafts. Priority will be given to concentrating naval resources in the East and South China Seas. By 2020, the Eastern fleet will possess 120 modern aircraft of JH-7A, SU-30Mk2, J-10, and $\mathrm{J}-11$ classes to accompany the $\mathrm{H}-6 \mathrm{~s}$ on attack missions within a radius of $400 \mathrm{~nm}$. The Southern fleet will have about 100 aircraft capable of in-flight refuelling as well as the carrier battle group that can handle conflicts in the Spratly Islands. (27)

From now on, naval air cover and stealth missile-carrying catamarans will take on most combat operations in in-shore areas (up to $200 \mathrm{~nm}$ ), replacing units without integrated combat systems. In peacetime, fishery protection and surveillance missions will be performed by the armed police, which is being provided with vessels decommissioned by the PLA Navy, and by civil paramilitary organisations, as described in Table 2. In disputed areas, such civilian-manned vessels are better suited to reducing tensions with neighbouring powers. ${ }^{(28)}$

China has also doubled its sealift capability in the past 15 years in response to the perceived threat from the Taiwanese independence movement. China's combined landing crafts could carry at least 30,000 troops and probably as many as 60,000 troops, including 37,000 on small, potentially unseaworthy vessels (see Table 3). Therefore, the widely-accepted estimate of a total sealift capacity of just $10,000-20,000$ troops by 2020 about two brigades - probably underestimates China's current and future sealift capabilities. ${ }^{(29)}$ In addition, by 2025 a series of landing dock ships and possibly helicopter carriers should be available to replace China's older

20. "Aircraft carrier prototype enters semi-public status" (Zhongguo hangkong mujian jiandaiji yuanxingji rujin bangongkai zhuangtai), 21 May 2010, http:///bbs.wforum.com/wmf/bbsviewer.php?trd id=67769 (consulted on 13 December 2011). "The surveillance aircraft intended for the Chinese aircraft carrier" (Zhongguo hangkongmu xiangmu de duanban: jianzai yujing ji), 21 May 2010, http://military. china.com/zh_cn/critical3/27/20100521/15945706.html (consulted on 13 December 2011).

21. "Russian Military: China's J-15 fighter jet not yet to par," The Moscow News, 6 July 2010.

22. The surveillance aircraft intended for the Chinese aircraft carrier" (Zhongguo hangkongmu xiangmu de duanban: jianzai yujing ji), 21 May 2010, http://military.china.com/zh_cn/critical3/ 27/20100521/15945706.html (consulted on 13 December 2011).

23. "US: China's 1st Aircraft Carrier Watched by Region," Associated Press, 12 April 2011.

24. In SSBN, the "SS" denotes a "submersible ship," the "B" denotes "ballistic missile," and the "N" denotes "nuclear powered."

25. Fang Zhen, "A personal estimate of the Chinese fleet of destroyers by 2015," Feiyang Junshi, www.fyjs.cn, 15 November 2010.

26. Ibid.

27. Jiang Yu, "Zhongguo Haijun zhuangbei de weilai shinian" (Prospects for equipment of the Chinese Navy in the next decade), Jianzai Wuqi - Shipborne Weapons, July 2010, pp. 23-34.

28. Ibid.

29. US DoD, Annual Report to Congress, Military Power of the People's Republic of China, 2008. 
Table 3 - Estimates for the Order of Battle Evolution, 2011-2025

\begin{tabular}{|c|c|c|}
\hline & 2011 & 2025 \\
\hline $\begin{array}{l}\text { Nuclear-powered ballistic missile } \\
\text { submarines }\end{array}$ & $\begin{array}{l}3+1 \\
\text { (old) }\end{array}$ & 6 \\
\hline $\begin{array}{l}\text { Conventionally-powered ballistic mis- } \\
\text { sile submarines }\end{array}$ & 1 & - \\
\hline Nuclear-powered attack submarines & 4 & 10 \\
\hline Air independent propulsion submarines & 6 & 22 \\
\hline Diesel electric submarines & 28 & 28 \\
\hline Obsolete diesel electric submarines & 27 & 10 \\
\hline Aircraft carrier & 1 & 2 \\
\hline Old anti-ship missile destroyers & 18 & - \\
\hline $\begin{array}{l}\text { Air defense/long range anti-ship } \\
\text { destroyers }\end{array}$ & 67 & 25 \\
\hline General purpose destroyers & 3 & \\
\hline Air defence frigates & 10 & \\
\hline General purpose frigates & 45 & 30 \\
\hline Landing dock ships & 2 & 6 \\
\hline Landing tank ships & 38 & 38 \\
\hline Small landing ships & 58 & 40 \\
\hline Mine countermeasures vessels & $\begin{array}{c}20 \\
(+80)\end{array}$ & 50 \\
\hline Patrol boats & 55 & $100-150$ \\
\hline Fleet support ships & 6 & 8 \\
\hline
\end{tabular}

Source: Authors' estimates based on shipbuilding projections. Saunders, Jane's Fighting Ships, 2011-12, pp. 129-168 tank landing ships, thus greatly enhancing the PLA's ability to project force across the Taiwan Strait. ${ }^{(30)}$

China has also made progress in developing command, control, communications, and intelligence (C3I) systems based on a very low-frequency radio system for communicating with its submarines and on Loran and Changhe long-wave navigation systems, which can be used for operations up to 1,000 nautical miles. From 2020 onwards, Chinese C3I will probably centre on the use of five geostationary and 30 high-earth orbiting satellites. China may have a fully integrated global information system by 2020 . Jiang Yu writes that "the period from 2010 to 2020 will be crucial in getting the navy equipped with integrated combat systems ( $x i t o n g$ peitao de zuozhan zhuangbei tixi系统配套的作战装备体系) so that it will be able to fight on the high seas." (31) China's procurement of new space systems will enhance its ability to detect and target naval activity in the Western Pacific Ocean following the Soviet example of active and passive radar satellites capable of collecting information on a target ship every 20 to $30 \mathrm{~min}$ utes for a duration that could exceed 70 days. ${ }^{(32)}$

China is developing long-range land-attack cruise missiles (LACMS) and anti-ship cruise missiles (ASCMs) that can be fired from land bases, bombers, submarines, and destroyers to attack targets, including air and naval bases, in Taiwan, Japan, or Guam.

Last but not least, the Second Artillery would play a central role in any confrontation with Taiwan because its forces now possess sufficient range and accuracy to target US forces in Japan and South Korea. ${ }^{(33)}$ The 2002 edition of the Second Artillery's Science of Campaigns shows how its missiles could help the air force and the navy achieve air and maritime superiority by striking the enemy's air and naval bases ${ }^{\left({ }^{34}\right)}$ and by creating maritime exclusion zones for aircraft carriers. ${ }^{\left({ }^{35}\right)}$ Anti-ship ballistic missiles also complicate US war planning. In a December 2010 interview with Japan's Asahi Shimbun, Pacific Command (PACOM) Commander Admiral Robert Willard asserted that the Dongfeng-21D (DF-21D) has reached an "initial operational capability." (36)

The implications for Europe of these PLA modernisations are two-fold.

On the one hand, European economic and trade interests could suffer from a maritime conflict in East Asia. In the South China Sea, the key issue is whether China will be able to achieve a transformation of the status quo through peaceful means and to what extent the various claimants have incentives to negotiate and compromise. As the strongest naval power in Southeast Asia (not including the United States Navy), China's incentive to employ a coercion strategy and checkmate Southeast Asian states is high. Although their influence on the decision-making process should be put into perspective, some voices within China explicitly call for military actions in the South China Sea. ${ }^{\left({ }^{37}\right)}$ Statistics remain to be compiled on the importance of the European Union maritime trade in East Asia, precisely because the EU has not taken the risks of conflict seriously. (38) But any

30. Jiang $Y u, o p$. cit.

31. Jiang Yu, op. cit

32. Norman Friedman, Seapower and Space, Annapolis, Naval Institute Press, 2000, pp. 157-162.

33. US Navy's Office of Naval Intelligence (ONI), "Worldwide Maritime Challenges," 2004, p. 20.

34. Yu Jixun, ed., The Second Artillery's Science of Campaigns, Beijing, 2002.

35. Ibid.

36. Mark Stokes, "Expansion of China's Ballistic Missile Infrastructure Opposite Taiwan," 18 April 2011, Project 2049 Institute.

37. For example: Long Tao, "Nanhai dongwu shiji chengshou, suoding feiyue yizhan zhizhan" (The time to use force has arrived in the South China Sea; Let's wage war on the Philippines and Vietnam to prevent more wars), Huanqiu Shibao, 27 September 2011.

38. Interview with a senior EEAS diplomat, Beijing, 24 July 2011. 
conflict would suddenly disrupt the flow of Chinese products to the Western hemisphere, causing shortages in many sectors made dependent on those imports by the massive deindustrialisation process in the European Union. In addition, trans-Atlantic solidarity may drag the EU into a conflict were one to erupt between China and the US over the South China Sea. During the 1995-1996 Taiwan Strait crisis, for example, the US formulated initial requests for support and assistance to allies in Europe. ${ }^{39}$ )

On the other hand, the prospects for maritime competition with China in the Indian Ocean, the Atlantic Ocean, or even the Mediterranean Sea are distant, and there is room for cooperation. There is no stated ambition from Beijing to project maritime power in these areas. ${ }^{(40)}$ Still, there is clearly no guarantee that China's strategy will not change. Realist international relations literature argues that intentions change with the accumulation of power. But while for Europe, the potential challenges of the PLAN modernisation rest primarily with maritime security issues in East Asia, Europe-China interactions in the military sphere during the past three decades have resulted in a hugely significant European contribution to the modernisation of the PLAN.

\section{Europe's contribution to China's naval modernisation before and after the embargo}

As Liu Huaqing stated in his memoirs, buying foreign weapons is an intermediary step to learn foreign techniques and fill gaps in capabilities and time. China's ultimate goal is to access the industrial capacity to produce advanced weapons without foreign technical assistance because foreigners won't share their newest techniques and do not have the same requirements. ${ }^{(41)}$

Deng Xiaoping's 1978 reforms opened the door for Western capitalism and technologies alike to enter China. ${ }^{(42)}$ With Washington's approval, the NATO allies (mainly UK, France, the Netherlands, Germany, and Italy) transferred armaments or dual-use technologies that helped upgrade the PLA in general and the PLAN in particular. For example, the Chinese Navy acquired:

- naval combat systems such as the Thomson CSF Tavitac from France and the ZJK-4, a Chinese copy of the Alenia Marconi Systems from Italy

- French air defence missiles in the form of Thomson CSF's Crotale Naval

- guns (French Creusot-Loire 100mm Compact)

- anti-submarine sensors in the form of the French Thomson Syntra sonars, including the DUUX-5 and DUBV-23 that inspired the SJD-8/9 and the DUBV-43

- French, Dutch, and Italian radars, including Thomson CSF's Sea Tiger, an export version of the French Navy DBRV-15, S-Band, 80 NM range; Dutch civilian air search REL-1, L-Band, 130 NM; Italian RAN 10S (that inspired Chinese Type 518 and 360 Seagul on Luhu-class destroyers and Jiangwei I/II -class and Jiangkai l-class frigates)

- electronic warfare systems (Dutch Hollandse Signaal Apparaten Rapids/Ramese; perhaps French DR2000U, Alligator X-band)

- Italian torpedoes (Whitehead A244S)

- naval helicopters (Aerospatiale Dauphin)

- jet engines (Rolls-Royce Spey engines)

- composite materials technology (from British Petroleum America and Sikorsky)

- Mark 46 Anti-Submarine Warfare torpedoes

- and diesel engines (French Pielstick, German MTU). ${ }^{(43)}$
During the 1980s, thanks mainly to these European equipment transfers in comparison, the United States only sold Gas turbines, helicopters, chaffs, and perhaps sonar - the Chinese Navy was able to upgrade or retrofit a dozen platforms (Luhu-class destroyers, Jiangwei I/II-class frigates, some old Luda-class destroyers) with better defensive capabilities. Even so, the gap between the Chinese Navy and the Soviet Pacific fleet remained considerable. China also developed the Exocet-like C-801 anti-ship missile and later made its own variant, the C-802, using a French small reactor from the company Microturbo. A limited number of those small turbo reactors had been sold legally to China. ${ }^{(44)}$ These forms of technology assistance helped the PLAN begin to recover from years of neglect during the Cultural Revolution.

The 1989 Tiananmen Square massacre resulted in a Western arms embargo limiting further weapons sales. European companies were nevertheless authorised to complete the contracts they had signed with China before 1989. In the aftershock of Washington's spectacular victory in the 1991 Gulf War against an entrenched army resembling the PLA, Beijing redefined its doctrine to be able to win "local wars under high-tech conditions," focusing on an approach built around "active defence." Modern technology was deemed to be the key to China's military transformation. With the end of the Cold War, formal military relations resumed with Russia. A starving post-Soviet defence industry was eager to secure Chinese orders and replace lost orders from East European militaries. However, the end of the Cold War also meant the lifting of restrictions on the export of Western dual-use technologies. Partially circumnavigating the Tiananmen embargo, China acquired space, laser, and ballistic missile technologies from the US, and aircraft, helicopters, ground vehicles, radars, marine engines, and machine tools from Europe. ${ }^{(45)}$

During the $9^{\text {th }}$ and $10^{\text {th }}$ five-year plans, China used Franco-German Pielstick civilian marine diesel engines to power every single one of its new frigates, amphibious ships, and auxiliary vessels. Those civilian diesel engines lacked the endurance of their military equivalents and were prone to failure at high speeds; however, they were key to China's naval modernisation. The design for the Jiangkai I/II-class frigates looked so similar to French LaFayette-class frigates sold to Taiwan that some argued that France had passed the blueprints on to China or that some information had filtered out from Taiwan. It seems, however, that this design was due mainly to China's careful study of all available data. Song-class conventional submarines were clearly inspired by the French Agosta; the information had most likely come from an operator and strategic ally, Pakistan. These platforms merged foreign technologies acquired legally or through espionage and resulted in genuine and apparently successful Chinese designs.

Knowing French and Italian combat systems, China's 709 Institute is reported to have developed a local area network to integrate the ship's sensors and weapons fire-control systems. China also copied Russian technol-

39. Interview with a senior European expert, Brussels, 8 March 2011.

40. Mathieu Duchâtel, François Codement, Alexandre Sheldon-Duplaix, "China's Sea Power, Reaching Out to the Blue Waters," China Analysis, The European Council on Foreign Relations, March 2011.

41. Liu Huaqing, Liu Huaqing huiyilu (Memoirs of Liu Huaqing), Beijing, Jiefangjun chubanshe, 2004.

42. Bates Gill, Taeho Kim, China's arms acquisitions from abroad: A quest for superb and secret weapons, Oxford University Press, 1995.

43. Norman Friedman, World Naval Weapon Systems.

44. See Sinodefence.com website for detailed data on those weapons systems, and A. Sheldon-Duplaix, "Les transferts de technologie et le développement de la marine de l'Armée Populaire de Liberation," oral communication, Sorbonne, Paris I, June 2007.

45. GAO report to Congress: "The PRC's effort to assimilate advanced US military technology, US Covernment monitoring of PRC technology acquisition efforts in the United States," 1999. 
ogy, and many of China's most recent weapon systems are predominantly based on Russian systems. Prominent exceptions include the Type 730 anti-missile gun, which is very similar to the Dutch Goalkeeper, a radar reminiscent of the Thales Smart-L; and an outright copy of the US-German RAM Close-In Weapons System for end-stage missile defence. This analysis is based on resemblances between systems. Generally there is not enough information available to pinpoint an espionage case.

\section{A global outlook: European-Chinese security cooperation and industrial competition}

The development of a blue-water capability by the PLA Navy could present Europe and the international community with new opportunities for maritime security cooperation. In many regional security crises, China is seen by some in Europe as a "swing power": if China remains neutral or opposed to a proposed international response, crisis resolution remains out of reach. During the past decade, this has been the pattern in Sudan, Myanmar, Zimbabwe, North Korea, and Iran, with varying outcomes.

Most importantly for Europe, however, the Continent's active diplomacy has completely failed to secure Chinese support for European positions and approaches. China has favoured a dialogue with the United States and overlooked European security concerns and cooperation requests. This is also true even in those areas of security policy where Beijing has incrementally adopted an approach more convergent with Western norms and practices, such as China's evolving approach on nuclear non-proliferation, which has moved in the direction of increasing convergence with the West, but largely as a result of US, not EU, engagement. (46)

The trend in China to overlook European concerns and requests can also be observed in the area of maritime security. In December 2008, the Central Military Commission took the unprecedented decision to send a PLAN flotilla to the Gulf of Aden to take part in an international counter-piracy operation. As the PLA Navy's first operational deployment outside of Asia, the move raised expectations in Europe that a window of opportunity had opened for bilateral cooperation in the maritime security sphere. The operations in the Gulf of Aden offered a platform for European military-tomilitary engagement with China at the operational level. Increased interactions with the Chinese navy could ideally initiate a virtuous circle of trust-building and mutual understanding.

At the same time, European naval officers and China-watchers were aware that the PLAN was taking advantage of this deployment abroad to gain operational experience. In the longer term, the operation could justify a Chinese decision to set up naval bases abroad for logistical needs because of the PLAN's limited capabilities for replenishment at sea. China had strong economic incentives to secure the area, such as the rise of maritime transportation insurance costs, ${ }^{(47)}$ which explains the CMC's decision better than China's ambition to become a responsible stakeholder in maritime security. On the whole, however, China's decision was welcome in Europe because the potential for setting up cooperative security mechanisms at sea exceeded the uncertainties over China's long-term strategic intentions.

At first China escorted Chinese and Taiwanese ships, outside of the three international coalitions, operation Atalanta (EU operation), operation Ocean Shield (NATO operation), and Combined Task Force-151 (a 25 nations coalition under US command). Communications with other navies were limited, and direct contacts with European naval ships were kept to a minimal level.
The United States took the lead in interacting with the PLAN, with the US Navy being the first to establish contact. US-China communication has led to an informal but intense dialogue at the tactical level with Combined Task Force 151. (48) In Europe, the debate centred in 2010-2011 on China's participation in Shared Awareness and De-Confliction (SHADE), a dialogue mechanism established in December 2008 to share information among participating navies on a monthly basis. China favours a geographical separation of the theatre of operations into responsibility zones where national navies would escort ships independently but in a coordinated way. ${ }^{(49)}$

While naval cooperation with China was slow in evolving, the number of ships attacked and hijacked kept rising throughout 2009 and 2010. (50) The area where pirates operate now affects a wide area from the Red Sea to the Seychelles and the Maldives, thus fuelling Indian anxieties about a Chinese naval presence near the sub-continent. ${ }^{(51)}$

While there is still room for improvement in EU-PRC naval cooperation, Europe and China are also competing over lucrative arms markets. For a long time Chinese naval weapons could not meet Western standards. Their poor quality and lower prices meant that they were a second best for countries such as Egypt, Algeria, Bangladesh, Sri Lanka, Albania, and Romania. The sale of eight Chinese warships and offshore patrol vessels to Thailand since the late 1980s marked a change. Although those vessels revealed serious shortcomings, they were purchased as an alternative to more expensive Western warships, and four - two large frigates and two offshore patrol vessels - were fitted with American systems obtained under the US FMS program. More recently, China has modernised Pakistani frigates, built two frigates and assisted in the indigenous construction of a third for Pakistan with Chinese weapons systems, including copies of French Crotale and Italian Aspide air defence missiles. This latter program came as a substitute to the purchase of second-hand Western platforms. Pakistan is also said to have selected China over France and Germany for the construction of its future Air Independent Propulsion submarines. (52) Chinese experts argue that arms sales to Pakistan serve as a window to showcase Chinese naval technologies to Middle East countries. ${ }^{(53)}$ China is now likely to offer an alternative to Western designs in the Asian, African, and South American markets. Chinese shipbuilders have participated in the Chilean Exponaval since 2002 and could tender for the modernisation of the Ecuadorian Navy and perhaps the construction of a Brazilian aircraft carrier at the end of the decade, in direct competition with France. ${ }^{(54)}$

\section{The arms embargo: Assessing Europe's calculated ambiguity}

The EU arms embargo towards China is the only EU embargo adopted before the construction of a Common Security and Foreign Policy (CSFP)

46. Evan S. Medeiros, Reluctant Restraint: The Evolution of China Non Proliferation Policies and Practices, Stanford, Stanford University Press, 2007.

47. Interview with a senior Chinese maritime security expert, Beijing, December 2010.

48. Gaye Christoffersen, "China and Maritime Cooperation, Piracy in the Gulf of Aden," Institut für Strategie, Sicherheits und Wirtschaftberatung, Berlin, 2010.

49. "China to lead anti-piracy patrols," South China Morning Post, 28 January 2010.

50. "No Stopping Them," The Economist, 3 February 2011.

51. Interview with a former USN participant, Washington, May 2011.

52. "Pakistan Begins Submarine Procurement Talks with China," Jane's Defence Weekly, 11 June 2010.

53. Interviews with Chinese experts of South Asia, Beijing, March 2010.

54. Stephen Saunders, Jane's Fighting Ships, various editions; Bernard Prezelin, Flottes de Combat, various editions. 
under the 1992 Maastricht Treaty. As such, the EU arms embargo against China is not a "common position" of the European Union, but a non-legally binding political declaration of the Council. It leaves open room for interpretation by member states on non-lethal arms, dual technologies, information exchange, training, and software. This distinction is reflected in Chinese by two different terms, "comprehensive embargoes" ( quanmian jinyun 全面禁运) as against "non-comprehensive embargoes" ( fei quanmian jinyun 非全面禁运 ). ${ }^{(55)}$ The 1989 EU arms embargo differs greatly from the 14 other arms embargoes that the EU was enforcing in early 2011. (56) It leaves room for some military transfers, albeit marginal. In addition, transfers of dual-use technologies and non-lethal military systems to China are not subject to strict European-level export controls. European arms embargoes usually include standardised language banning all kinds of military cooperation with targeted countries, including "prohibition to grant, sell, supply, or transfer technical assistance, brokering services and other services related to military activities." (57) As a result, according to official European statistics, in 2009, five European countries exported 58.6 million euros' worth of military technologies to China (not including Hong Kong and Macau), and issued licenses worth 209.4 million euros, while 35 licences were denied to China. ${ }^{\left({ }^{(5)}\right)}$ As to the flow of dual technologies, it is currently not being tracked in any systematic way.

In 2003-2004, China pressed the EU to lift the arms embargo by using several arguments, including:

- the arms embargo was outdated because China had changed;

- lifting the embargo would be a largely symbolic decision;

- China could not be compared to other states under European embargoes; and

- the embargo was preventing the emergence of a genuine EU-China strategic partnership.

In Europe, anti-embargo advocates argued that it would not result in major arms sales and that the level of transfers of military technologies would remain stable. Michèle Alliot-Marie, then French Minister of Defence, stated that since the modernisation of China's defence industry was irreversible, lifting the arms embargo would slow down the modernisation of China's military-industrial complex because it would remove an incentive to self-reliance. ${ }^{(59)}$

At the same time, several European states and arms companies were seriously contemplating the prospect of selling weapons systems to China, while Chinese experts were listing the benefits that China could derive, contradicting the argument made by Michèle Alliot-Marie. For example, the Chinese State Shipbuilding Corporation (CSSC)-sponsored magazine Naval and Merchant Ships explained that French technology would help reduce a growing gap with American $4^{\text {th }}$ and $5^{\text {th }}$ generation fighters: "[Even] if none of the European fighters can compete with the F-22 and F-35, French Rafale and European Typhoon are [still] considered to be better than the upgraded American $3^{\text {rd }}$ and $4^{\text {th }}$ generation aircraft sold to Taiwan and other Asian neighbours. Intermediary $3^{\text {rd }}$ and $4^{\text {th }}$ generation techniques are [thus] needed and acquiring European $3^{\text {rd }}$ and $4^{\text {th }}$ generation fighters would help train better pilots and close the gap with America's considerable advance." (60)

In 2004-2005, there were calls in Europe to link termination of the embargo to human rights. Again in 2007, EU Commissioner for External Relations Benita Ferrero-Waldner told Premier Wen Jiabao that three human rights conditions had to be met before the lifting of the arms embargo. ${ }^{(61)}$ Other experts called for reciprocity. François Godement and John Fox sug- gested lifting the embargo in exchange for Chinese cooperation to prevent Iran from developing nuclear weapons. ${ }^{(62)}$ Beijing has thus far rejected the notion of a grand bargain with Europe to lift the embargo. Hence China has never clearly explained what would be the benefits for the EU of lifting the arms embargo beyond a vague assurance that the comprehensive strategic partnership would be enhanced - and the unstated but clear benefits for European arms trading companies. In addition, despite the gradually fading hope of encouraging China's transformation into a liberal democracy in the face of Beijing's persistent refusal to pursue political reform, there has still been no consensus in Europe over what policy goals should be achieved through the lifting of the arms embargo.

The construction of an EU-level arms-control mechanism is still a work in progress. In March 2005, British Prime Minister Tony Blair declared that the adoption of a strict and legally-binding Code of Conduct was the sine qua non condition for lifting the embargo. ${ }^{(63)}$ Such an approach would have included a unified list of items banned from export to China. In 20042005, (64) Washington tried to limit European Union defence and dual-use technology exports to China by suggesting - so far unsuccessfully - a new version of the Cold War-era Coordinating Committee for Multilateral Export Controls (CoCom).

On 8 December 2008, the EU Council finally replaced its 1998 nonlegally binding Code of Conduct with Common Position 2008/944/CSFP. (65) The Common Position was adopted as a means of reinforcing the EU's export control mechanisms, and without being linked to the post-Tiananmen China arms embargo. Member states are obliged to bring their policies into line with the Common Position, but the implementation is not subject to the jurisdiction of the European Court of Justice. (66) Under the Common Position, European exports of military technology must respect eight criteria, including the respect for human rights in the country of destination; the preservation of regional peace, security, and stability; and limitations on the risk of re-export. The adoption of the Common Position reinforces the EU's arms control mechanisms, but a certain amount of ambiguity remains regarding the extent to which the Common Position can prevail over

55. Wang Yifeng, "Zhongguo cong nali mai xianjin wuqi: Zhongguo jungou shichang fenxi" (Where do China advanced weapons come from: An analysis of the Chinese arms market), Jianzai Wuqi - Shipborne Weapons, 2, March 2004.

56. Burma, Côte d'Ivoire, North Korea, Democratic Republic of Congo, Republic of Guinea, Eritrea, Iran, Iraq, Lebanon, Liberia, Sierra Leone, Somalia, Sudan, Zimbabwe.

57. Council of the European Union, "List of EU embargoes on arms exports, UN Security Council embargoes on arms exports and arms embargoes imposed by the OSCE," 27 April 2010, http://register.consilium.europa.eu/pdf/en/10/st09/st09045.en10.pdf (consulted on 8 April 2011).

58. "Twelfth Annual Report according to Article 8(2) of Council Common Position 2008/944/CFSP defining common rules governing control of exports of military technology and equipment," Official Journal of the European Union, vol. 54, 13 January 2011, http://eur-lex.europa.eu/LexUriServ/ LexUriServ.do?uri=OJ:C:2011:009:FULL:EN:PDF (consulted on 14 December 2011).

59. "France Urges End to China Arms Embargo," Financial Times, 15 February 2005.

60. Naval and Merchant Ships, no. 4, 2005.

61. These were the ratification of the UN Covenant, the release of Tiananmen political prisoners, and the abolition of labour camps. Jerker Hellström, "The EU Arms Embargo on China: A Swedish Perspective," Swedish Defence Research Agency, 2010

62. John Fox, François Codement, A Power Audit of EU-China Relations, op. cit.

63. Hellström, "The EU Arms Embargo on China," op. cit.

64. Sébastien Decreton, "La question de l'embargo sur les ventes d'armes à la Chine," Critique Internationale, no. 43, 2009, pp. 109-132.

65. "Council Common Position 2008/944/CSFP of December 8, 2008 defining common rules governing control of exports of military technology and equipment," Official Journal of the European Union, 13 December 2008, http://eur-lex.europa.eu/LexUriServ/LexUriServ.do?uri=OJ:L:2008:335:0099:0 103:EN:PDF (consulted on 14 December 2011).

66. Mark Bromley, "The Impact on Domestic Policy of the EU Code of Conduct on Arms Exports, the Czech Republic, the Netherlands and Spain," SIPRI Policy Paper, no. 21, October 2008. 
individual members' export decisions based on national interests. Each member can still make its own interpretation of the Common Position to justify arms transfers if it so chooses. ${ }^{(67)}$

Addressing the issue of dual-use technology transfers, the European Council on 5 May 2009 adopted Regulation No. 428/2009 setting up a Community regime for the export, transfer, brokering, and transit of dualuse items. ${ }^{(68)}$ The Regulation includes a list of dual-use items drawing from the practice of multilateral international agreements and export control regimes, including the Wassenaar Arrangement, the Missile Technology Control Regime, and the various international documents regulating the international trade of dual-use items used in manufacturing Weapons of Mass Destruction. But the final decision on implementation of the Regulation still lies in the hands of the EU member states. ${ }^{(69)}$

In reality, the debate over lifting the arms embargo made the EU realise the dramatic trans-Atlantic implications of such a decision. Threats of sanctions and loss of access to the US market have effectively deterred European defence firms such as the UK's BAE Systems from supporting such a move. ${ }^{(70)}$ Officially, the EU still considers lifting the arms embargo an "ultimate goal," but in practice there is a tacit agreement among European governments that the issue should be set aside. No member state can launch a credible policy review on this issue. Hence, when in late January 2010, Spain's foreign minister said that Madrid was "weighing the pros and the cons" of lifting the embargo, there was not even a strong public Chinese reaction. ${ }^{(71)}$ The sense among most serious observers of Spanish foreign policy was that Spain was pushing its own China agenda, not describing a serious EU-wide position. Indeed, since the $200710^{\text {th }} \mathrm{EU}$-China summit, mention of the arms embargo has been removed from the final joint communiqués of the annual summits. ${ }^{(72)}$

The 2011 financial crisis in Europe provided China with a new opportunity to raise the embargo issue. In November 2011, European countries asked Beijing to pursue European Sovereign Bonds through the Financial Stability Fund. On a subsequent trip to Europe, President $\mathrm{Hu}$ Jintao stated that the easing of Europe's restrictions on exports of high-technology products was still a priority, without explicitly linking the lifting of the arms embargo to possible Chinese assistance in overcoming Europe's debt crisis. ${ }^{(73)}$ The major weakness of Europe's calculated ambiguity is that China can raise the embargo issue every time the $\mathrm{EU}$ attempts to further develop the EU-China strategic partnership. But the likelihood of a European policy shift on the embargo in the mid-term is very low, in view of the factors described above.

\section{The international Law of the Sea and Europe's long-term strategic interests}

One of the problems encountered by Europe in crafting a policy towards East Asian maritime disputes is that there is only a very slim chance that international law will prove helpful in providing solutions to the competing sovereignty claims and security problems of the region. China does not recognise the competence of the International Court of Justice or other tribunals for adjudicating maritime disputes. On 25 August 2006, the Chinese government added a reservation under Article 298 of the United Nation Convention on the Law of the Sea (UNCLOS), under which it does not accept UNCLOS procedures to solve most categories of territorial disputes. ${ }^{(74)}$ Article 298 defines compulsory procedures for legally binding decisions in case of dispute between signatory states. China thus rejects the compe- tence of the International Tribunal for the Law of the Sea (ITLS), the International Court of Justice (ICJ) or any arbitration tribunal to settle disputes related to sea boundary delimitations, military activities and "disputes in respect of which the Security Council of the United Nations is exercising the functions assigned to it by the Charter of the United Nations." (75)

Even before the ITLS, the outcome of a settlement on the sovereignty over the Diaoyu/Senkaku islands would be unpredictable, given the flaws of both China's and Japan's legal arguments. ${ }^{(76)}$ The situation in the South China Sea is slightly different. "Historical rights" ( lishixing quanli 历史性权 利) are used as a basis for China's territorial claims under article 14 of the 1998 Law of the PRC on the EEZ and the Continental Shelf. (77) China's rejection of the United Nations Convention on the Law of the Sea (UNCLOS)'s geographical approach to territorial delimitation in the South China Sea, based on the distance from the seashores, is not acceptable to the EU. So far, European countries individually, and the EU as a whole, like the United States, have refrained from taking a stance on sovereignty in the South China Sea.

The EU's interpretation of UNCLOS also diverges from China's on the definition of innocent passage in Economic Exclusive Zones. The Chinese government signed UNCLOS in 1982. When the Chinese delegation deposited its ratification instrument with the United Nations on 7 June 1996, it made four reservations, stating, "The provisions of the United Nations Convention on the Law of the Sea concerning innocent passage through the territorial sea shall not prejudice the right of a coastal state to request, in accordance with its laws and regulations, a foreign state to obtain advance approval from or give prior notification to the coastal state for the passage of its warships through the territorial sea of the coastal state." (78) In 2002, China passed a law restricting survey and mapping activities in its EEZ and requiring foreign states to obtain permission from the Chinese authorities before conducting such surveys. China is among the 12 states that retain laws asserting the right to regulate military activities in their EEZ. (79) The international Law of the Sea limits a state's sovereignty over its EEZ to economic exploitation and scientific exploration. But while the regime of the territorial seas applies to economic activity, the regime of

67. Paul Holtom, Mark Bromley, "The Limitations of European Union Reports on Arms Exports: The Case of Central Asia," SIPRI Insights on Peace and Security, no. 2010/5, September 2010.

68. Council Regulation (EC) No. 428/2009 of 5 May 2009 setting up a community regime for the control of exports, transfer, brokering, and transit of dual-use items, www.consilium.europa.eu/eeas/foreignpolicy/non-proliferation,-disarmament-and-export-control-/security-related-export-controlsi.aspx?lang=en (consulted on 14 December 2011).

69. May-Britt Stumbaum, "Risky Business? The EU, China and dual-use technology," EUISS Occasional Paper, no. 80, October 2009.

70. "British Arms Firm will Spurn if Arms Embargo Ends," The Times, 22 February 2005. Interview with a senior EU politician then in charge of defence policy, Paris, 18 December 2009.

71. "EU Presidency Reconsidering China Arms Embargo," EU Observer, 27 January 2010.

72. Huang Dong, "Oumeng jiechu duihua wuqi jinyun shijian zhong de meiguo yinsu" (The US role and the EU's arms embargo towards China), Waijiao pinglun, no. 5, 2010, pp. 91-102.

73. Jiang Junbo, "The Dragon is No White Knight," Asiatimes online, 3 November 2011.

74. United Nations, Division for Ocean Affairs and the Law of the Sea, "Declarations or Statements upon UNCLOS ratification," www.un.org/Depts/los/convention_agreements/convention_declarations.htm \#China\%20after\%20ratification (consulted on 14 December 2011).

75. Ibid.

76. Steven Wei Su, "The Territorial Dispute over the Diaoyu/Senkaku: An Update," Ocean Development and International Law, no. 36, 2005, pp. 45-61.

77. Law of the People's Republic of China on the Exclusive Economic Zone and the Continental Shelf, adopted by the Standing Committee of the 9th National People's Congress, 26 June 1998.

78. UN, Division for Ocean Affairs, op. cit.

79. Peter A. Dutton, "Caelum Liberam, Air Defense Identification Zones Outside Sovereign Airspace," The American Journal of International Law, vol. 103, no. 4, October 2009, pp. 691-709. 
the high seas applies to military activities. Therefore, the legal basis for coastal states to reject other states' military activities in their EEZ, including surveillance and exercises, is weak. UNCLOS puts forward the notion of "due regard" that states should have to the rights and duties of coastal states, and of compliance to the national laws and regulations of the coastal states. Moreover, military activities in the EEZ of a coastal state could be interpreted in some cases as threatening and thus inconsistent with both the 1982 UNCLOS and the UN Charter.

However, China rejects activities that it considers hostile, such as "espionage." Mark Valencia, a maritime security expert at the Nautilus Institute, argues that China could tolerate passive collection of electronic intelligence, but that interference with Chinese military communications to test its defensive systems would provoke a military reaction. ${ }^{(80)}$ China has also remained ambiguous on whether the Chinese Navy would enforce the rejection of military activities without prior notification only in China's internationally recognised EEZ - calculated from China's coastal baseline or also in the maritime territories claimed by the PRC in the East and South China Seas.

The restrictions that the Chinese government wants to apply to innocent passage in China's claimed EEZ are problematic for Europe for several reasons:

- They represent a factor of strategic instability that has caused military incidents such as the March 2009 harassment of the US surveillance ship USNS Impeccable by Chinese paramilitary forces 75 miles south of Hainan. ${ }^{(81)}$

- Unlike the EU - and despite the fact that it has not ratified the UNCLOS - the United States refers to UNCLOS to legitimate its military activities in China's EEZ. Risks of naval incidents with European military vessels are minimal since France, Britain, and Germany's annual or biannual deployments to China are related to pre-approved port-visits, not military intelligence collection efforts.

- China's rejection of innocent passage in its EEZ may be part of a revisionist strategy on the international Law of the Sea that could contradict European interests. With the exception of Portugal, the EU overwhelmingly supports UNCLOS as the basis for international maritime security. In the past, China has successfully built large coalitions at the Human Rights Council of the United Nations. China's legal revisionism could weaken the EU and US positions. ${ }^{(82)}$

\section{Conclusion: Understanding the EU's true strategic relevance vis-à-vis China}

The EU has more interests in PLAN modernisation and maritime security in East Asia than has traditionally been recognised. Indeed, the modernisation of the PLAN raises bilateral, trans-Atlantic, and global issues for the EU's nascent common foreign and security policies.

On the bilateral EU-China front, the first challenge for Europe is to reinforce its independent capacity to engage in strategic assessment; otherwise it will not be able to break away from a normative approach that fails to address China's military modernisation in a comprehensive manner. There is a need in Europe for strategic reassurance on long-term Chinese intentions, as there is a need for assurances that China will exercise selfrestraint in its maritime disputes with weaker neighbours.

European policies should focus on simple goals: making European concerns clear and unambiguous to China; and integrating maritime security

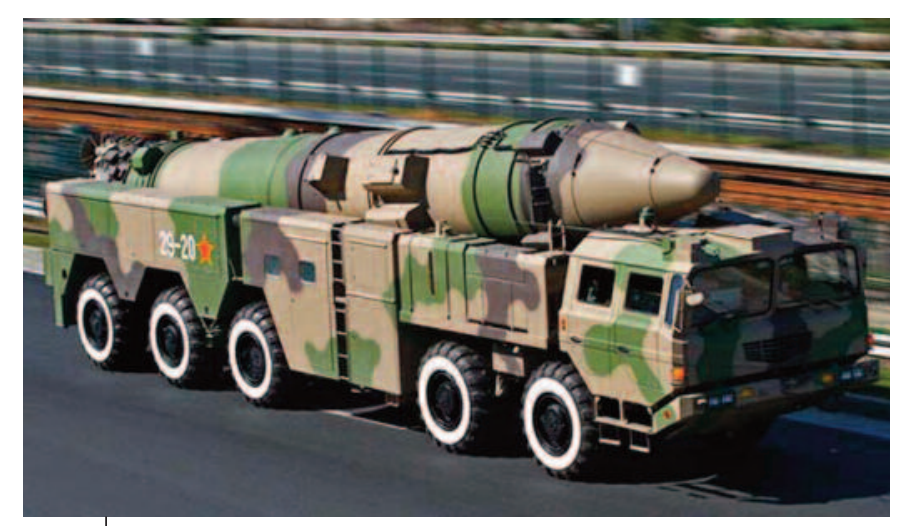

A DongFeng 21-D on the Highway (see p. 36).

๑ Wikimedia/Max Smith

into the Europe-China strategic dialogue and into European dialogues with the US and East Asian states. Only through such a process will Europe be able to explore cooperative engagements with China on counter-piracy, non-combatant evacuation operations, and rescue and relief operations on a sound basis.

Europe has a strong interest in bringing China into full compliance with UNCLOS. Chinese restrictions on freedom of navigation for military ships in the EEZ, and the notion of "historical maritime rights," run counter to French and British approaches to the Law of the Sea. In a crisis, those gaps would increase the difficulty for Europe and China of finding common ground for crisis resolution. Additionally, Europe should pay attention to the challenges posed by China's adoption of a strategy of "legal warfare," which seeks to form an international coalition to renegotiate the UNCLOS, undermining European interests.

Furthermore, the trans-Atlantic partnership determines to a large extent the EU's approach to maritime security in East Asia. There is no reason to think that new conditions would allow termination of the arms embargo towards China. The trans-Atlantic partnership could also drag Europe into a maritime conflict in East Asia. If the US intervened militarily in a regional crisis, European allies would almost certainly be asked to contribute politically or militarily. As such, Europe should press the United States to ratify UNCLOS in order to reinforce Europe and US common positions on this issue.

Finally, competition on the international arms market seems inevitable, and Europe will need to think hard about how it can stop the leakage of sensitive military and dual-use technologies to China.

In the short and longer terms, the EU and China have a number of common interests in international stability that call for improving naval cooperation, including humanitarian relief operations, repatriation operations from war zones, and anti-piracy operations. The maritime front will thus remain an area where increased engagement between the EU and China should be pursued.

80. Mark J. Valencia, "Foreign Military Activities in Asian EEZs: Conflict Ahead?", The National Bureau of Asian Research, NBR Special Report no. 27, May 2011

81. Mark Valencia, "The Impeccable Incident, Truth and Consequences," China Security, vol. 5, no. 2, Spring 2009, pp. 22-28.

82. Richard Gowan, Franziska Brantner, A Global Force for Human Rights? An Audit of European Power at the UN, European Council on Foreign Relations, September 2008. 